Article

\title{
Game-Based Learning in Project Sustainability Management Education
}

\author{
Elina Jääskä *, Kirsi Aaltonen and Jaakko Kujala
}

check for updates

Citation: Jääskä, E.; Aaltonen, K.; Kujala, J. Game-Based Learning in Project Sustainability Management Education. Sustainability 2021, 13, 8204. https://doi.org/10.3390/ su13158204

Academic Editors: Kris Law, Yuk-Ming Tang and Jukka Majava

Received: 22 June 2021

Accepted: 21 July 2021

Published: 22 July 2021

Publisher's Note: MDPI stays neutral with regard to jurisdictional claims in published maps and institutional affiliations.

Copyright: (c) 2021 by the authors. Licensee MDPI, Basel, Switzerland. This article is an open access article distributed under the terms and conditions of the Creative Commons Attribution (CC BY) license (https:/ / creativecommons.org/licenses/by/ $4.0 /)$.
Department of Industrial Engineering and Management, Faculty of Technology, Industrial Engineering and Management, University of Oulu, 90570 Oulu, Finland; kirsi.aaltonen@oulu.fi (K.A.); jaakko.kujala@oulu.fi (J.K.)

* Correspondence: elina.jaaska@oulu.fi

\begin{abstract}
Projects and project-based activities account for over 30\% of the global GPD and act as significant vehicles in the transition towards a more sustainable future. Sustainability strategies are typically enacted and implemented through projects in project-based organisations and firms. Incorporating sustainability principles into the project, product, and service management processes with successful project decision making is a challenging task and requires new personnel competencies and skills. Project sustainability management education requires the embedding of sustainability principles into project management education in a purposeful, integrative, innovative, and seamless manner. One way to facilitate this process is educational games. Active and experiential teaching methods will enable learning and practising complex project management activities in a simulative environment and are challenging at the same time. To extend knowledge of designing and using educational games for project sustainability management education, we explore the development and use of a novel educational game solution called the Project Business Game. It provides students and teachers with a computer game environment and game-based learning solution in which project planning, stakeholder management, cost management, decision making, and risk management skills can be enhanced by means of experiential, situational, and problem-based learning. The use of the game was explored in the context of educating European students of 'Junior Expert in Circular Economy' on a blended learning course in spring 2021. Action design research was applied as a research method. The results describe the requirements and goals for the instruction and the game design process based on these needs and experiences of the implementation. The findings indicate the strong suitability of using game-based learning methods to teach project sustainability management and create positive student experiences of achieving learning goals and improving engagement.
\end{abstract}

Keywords: educational games; game-based learning; game design; gamification; project sustainability management

\section{Introduction}

Projects are a significant driver in the transformation towards sustainability and circular economy. Sustainability thinking, integrated into business strategies, has a direct impact on project management processes and practices of project-based organisations. Sustainable project management requires that triple-bottom lines of environmental, economic, and social aspects are considered in project management decision making and practices throughout the project lifecycle. In practice, it is recommended that sustainability aspects and thinking should be included in the project, product, and service management processes in alignment with sustainable development principles and goals [1,2]. Sustainability strategies of the organisations affect project management, delivery, and support processes, and project deliverables. In practice, the sustainability of a project can be viewed from the perspective of sustainable project management processes and the sustainability of the project products. Project sustainability management frameworks have been studied and developed, especially in the context of manufacturing and construction project management [3,4], from software or information system project management perspectives [5-7]. 
Incorporating a sustainable perspective into project management processes and practices positively affects project success [8] and supports project performance [9]. Effective sustainability management can also increase the competitive advantage of companies. Consequently, project managers with project sustainability management skills and competences are needed to guarantee future business success. Project management higher education must recognise and respond to the requirements derived from the nexus of sustainability and project management. Sustainability-related decision making in the context of projects is not conducted in isolation, but it needs to be taken into account and balanced with other project-related demands and requirements. A challenge for project management education is to incorporate project sustainability thinking and management as an integral and harmonised part of project management teaching instead of as separate, independent disciplines.

Project managers need additional skills, on top of traditional project management skills, that qualify them to identify, plan, and execute projects and produce deliverables or products according to sustainability principles and objectives. Teaching these skills in an engaging manner is a challenging task for which novel pedagogical tools and approaches are needed. Educational games provide students with an environment in which real-life phenomena are simulated. Essential skills such as project cost management, informed decision making, stakeholder engagement, uncertainty management, and project control can be practised while playing the game. This paper describes and illustrates the design process of a game-based learning method to solve teaching and learning challenges related to project sustainability management skills. Experiences of the method from the teachers' and learners' perspectives are also explored.

Experiential learning theory, in which knowledge is created through the transformation of experience [10], is a foundation for game-based learning methods, enhancing and completing learning in higher education. Other learning theories, such as constructivism [11], situated learning [12], and problem-based learning [13], also form the pedagogical background for the use of game-based learning methods. The game environment facilitates the understanding of how to manage connections between people and activities, integration and uncertainty. In addition to discipline-based skills, game-based learning can improve students' generic skills, such as decision making, problem-solving, and collaboration, all of which are competences that project managers need to practise and master. Learning can be achieved and enhanced by means of concrete and active experimentation, abstract conceptualisation, reflective observation, and feedback [10].

This study aims to provide new knowledge about how a computer-game-based learning method can be successfully designed and applied to teach sustainability management in projects. The research question of this paper is: how can game-based learning be utilised in project sustainability management education? Educational games offer learners a safe setting to practise management skills in a simulative environment without fear of failure or harmful consequences, which is not possible in real-life projects. The use of educational games in teaching provides students with an experiential learning opportunity, which makes them active learners, improves their learning outcomes, and develops project sustainability management competence.

This paper studies the development and use of an educational game called the 'Project Business Bame' (PBG) in the context of educating European students of the 'Junior Expert in Circular Economy' blended learning course in spring 2021. The learning approach and insights are presented as follows. First, we present the concepts of project sustainability management, gamification of education, and game-based learning to map the somewhat varying terminology in the existing literature. We enlighten the overall experiences of using gamified education methods in university teaching of management and engineering subjects as a brief background review. Next, we introduce game design elements to explain the principles of the educational game definition and configuration of this case study. We describe the project sustainability management teaching case, the game environment, and the educational philosophy connected to the game, then continue by describing the design process of how the sustainability theme was incorporated into PBG, based on the project 
management learning goals of the course module. Finally, we present, analyse, and draw conclusions about students' experiences of using game-based learning as a method to learn project sustainability management. Student surveys were conducted to collect feedback on the course module and the use of PBG as an educational method. Survey data is used to support the analysis and discussion of the potential benefits and disadvantages of the learning approach in the PBG case.

\section{Theoretical Background}

This chapter consists of a brief literature review introducing the concepts of project sustainability management, gamified learning, and educational game design elements.

\subsection{Project Sustainability Management}

Sustainable project management is 'the planning, monitoring, and controlling of project delivery and support processes, with consideration of the environmental, economic, and social aspects of the life cycle of the project's resources, processes, deliverables, and effects, aimed at realising benefits for stakeholders and performed in a transparent, fair, and ethical way that includes proactive stakeholder participation' [2] (p. 17). This comprehensive definition sets the baseline for project sustainability management competence development. At the company level, sustainability affects portfolio decisions, and sustainability assessment frameworks can be used to align innovations, products, and project portfolios with sustainability strategies [1,14,15].

Different frameworks to assist decision making when evaluating projects in different life cycle phases from environmental, economic, and social aspects can be used [16]. One framework developed by Sánchez [16] integrates sustainability issues into project management, containing methods for stakeholder analysis, strategy mapping, and KPI definitions, resulting in ranked and optimised project portfolios. This framework can be used for project sustainability analysis, control or change of activities. A new 'school of thought' was introduced by Silvius [17], where sustainability in project management manifested as considering societal perspective, stakeholder management, value-based approaches, and triple-bottom-line criteria. More recent research has found that four features depict sustainable project management: holistic triple-bottom-line thinking (not just profitability), sustainability included in the entire project life cycle and outcomes, strong stakeholder involvement, and ethical contribution to society [3].

Silvius and Schipper [2] stress the role of stakeholders in their definition of sustainable project management, urging transparency, accountability, and proactivity in project stakeholder management. Management for stakeholders instead of the management of stakeholders widens stakeholder influence on sustainable project management [18]. Therefore, project sustainability strategy needs to be thoroughly considered and incorporated early enough in the project initiation and planning phases to ensure strong project organisation and stakeholder engagement $[15,19]$. Early engagement of external stakeholders in the project's decision making is particularly relevant from the perspective of social sustainability. In project contexts, social impact assessment (SIA) as part of the environmental impact assessment process is a value-adding tool to gain external stakeholders' insights, as well as commit them to the project [20]. Sustainable supplier practices are also crucial for addressing the three pillars of sustainability and include responsible supplier selection decisions and the development of suppliers' sustainability competences and capabilities during the project $[21,22]$.

The most important project sustainability-related decisions are typically made in the project design stage [19]. Project product-related decisions have significant implications for sustainability over the project lifecycle and value creation. Incorporating sustainability thinking into the product design early enough also protects the project from costly change requests during the later stages of the project and facilitates the social licence to operate the project. At this point, product- and technology-related innovation investments that advance economic sustainability can be made. Innovation investments, however, can also 
bear great uncertainty, as different uncertain technological solutions are explored, and the project team, therefore, needs to carefully assess the potential risks and opportunities of these investments [23]. HSEQ, and particularly safety management, is also an essential part of economic, environmental, and social sustainability. Balancing safety-related costs and benefits is a highly challenging task for the project manager. While safety has traditionally been understood as a lack of accidents or incidents, the contemporary and sustainability emphasis is on a proactive approach, viewing safety as a positive presence that enhances the capacity to cope with daily work and its variability [24].

Toljaga-Nikolic et al. [25] state that incorporating the sustainability dimension into project management increases the responsibility and timeline of the project manager beyond the project's end. Ethically right and fair decisions need to be made, and excellent communication skills are essential for dealing with a substantial number of stakeholders. IPMA Individual Competence Baseline Version 4 Chapter 4.3.3.4 includes the statement that project managers need to be capable of identifying and ensuring project compliance with relevant sustainability principles and objectives [26]. Systems thinking and interpersonal, normative, anticipatory, and strategic competences are seen as five key competences in sustainability $[27,28]$. Project sustainability management education must respond to these competence requirements derived from implementing sustainability strategies at the company and project levels.

\subsection{Gamification of Education and Game-Based Learning}

Game-based learning methods provide teachers with an environment where complex systems, such as projects, can be modelled and project phenomena can be simulated. In a gamified learning environment, students can apply and test what they have learned from lectures and study materials.

Experiential learning theory, where knowledge is created through the transformation of experience [10], is a foundation for game-based learning methods that enhance and complete learning in higher education. Concrete and active experimentation, abstract conceptualisation, reflective observation, and feedback foster learning. Berggren and Söderlund [29] emphasise the importance of social learning in project management education as a format of articulation and reflection, individually or as a group, that enables knowledge co-production. Debriefing sessions to discuss, analyse, and share game-based learning experiences after classes are typically conducted.

Gamification of education and game-based learning are practical methods of implementing learning. Gamification is traditionally defined as 'the use of game design elements in non-game contexts' [30] (p. 9). Playing (a game) for fun and learning is a natural behaviour for human beings. Another definition useful in an educational context is formulated by Zichermann and Cunningham [31] (p. xiv), who say that gamification is 'the process of using game thinking and game mechanics to solve problems and engage users'. When using gamification in project management teaching, student engagement and problem-solving are apparent subjects to be pursued or influenced. A third definition of gamification [32] highlights the experimental nature of gamification and the role of the gamified service customer, both as the value user and value producer. Co-creation of learning experience takes place when both instructor and learner add value to the mutual learning process in a gamified educational setup.

Gamification as an educational method means adding game elements, such as points, badges, levels, and leaderboards, into the traditional instruction method. Game elements are used to encourage students to engage with content, motivate action, and influence behaviour but do not include digital or analogue games [33,34]. Landers [35] defines gamification of education and learning more extensively, including assessment, challenge, human interaction, and rules/goals being game elements that promote learning and achieving learning goals. He emphasises that the successful use of gamification in education means the use of game characteristics together with instructional content that affects a learner's behaviour or attitude. 
Game-based learning differs from gamification because it includes an actual game to teach knowledge and skills [36]. In game-based learning, the game creates the learning experience. Game-based learning is an approach and method that activates students to learn by experience [10]. Game-based learning provides learners with a learning experience in which they can try different strategies and decision-making procedures when pursuing the game goals. At the same time, they learn how to apply theory-based processes and knowledge in a simulative environment. Playing a game typically helps students remember the learning topic and context with repetition, emotion, and immersion in the gaming situation.

Games and simulations are sometimes discussed as similar educational concepts. In this document, we use the distinctive approach, where the educational game is seen as an artificial situation in which players have rules, challenges, conflicts, and co-operation, and the goal is of an educational nature. Simulations are dynamic systems used in learning contexts representing simplified reality but do not necessarily have a quantifiable outcome of winning or losing, which separates them from games [37]. Simulation games combine these characteristics, and the PBG investigated in this case study could be categorised as a simulation game.

\subsection{Experiences of Game-Based Learning}

The influence of game-based learning methods on learning outcomes (cognition and knowledge acquisition), student engagement (motivation and affection), and learning together as a social construction (sociocultural) has been studied. DeFreitas [38] writes about the difficulty of identifying and measuring the efficacy of game-based learning due to its multidisciplinary nature. In the literature, the impacts are often presented from education science, game science, neuroscience, and information science perspectives instead of as cross-disciplinary analysis and synthesis. This paper describes the impacts of game-based learning from a game studies viewpoint.

The most discussed feature of game-based learning is its effect on learner motivation. Playing is a natural human behaviour and is important for cognitive development and learning, regardless of age. Educational games entertain and increase interest, resulting in intensive interaction with the learning subject. Player engagement is also a popular theme as a consequence of using games. Engagement manifests on a cognitive level as mental processing, emotional processes causing affective engagement and behavioural and sociocultural engagement. Adaptivity to learners' existing knowledge and the idea of graceful failing as part of the learning process also characterise game-based learning [39].

Gamified learning is adopted in higher education merely in the computer science subject area $[40,41]$. Business studies and science are the next two disciplines in which gamification of education and game-based learning is applied. Research from engineering disciplines is scarce. Early adoption of gamified learning into computer science rather than other disciplines is explained by the challenges that instructors face when they want to use and manage complex software systems [41].

Game-based learning provides students with a risk-free environment to practise decision making in complex project environments without the risk of serious harmful consequences for a project or budget. The use of an educational game in project management decision making was studied by Rumeser and Emsley [42], who found that decision-making performance was positively affected by both complex and less complex games that simulated a project.

Several research results show that educational gamification positively affects the achievement of learning goals set for a specific course or class [43-46]. These studies demonstrate that practical activities in gamified situations and educational games help students to understand and apply what was taught as a theory. Hamzeh [45] found simulation games useful for facilitating class instruction and increasing understanding in engineering education of lean construction principles. Positive influence on developing critical thinking skills and student satisfaction was observed. The study of student engagement 
and challenge in a game-based learning environment both quantitatively and qualitatively indicated a positive effect on learning [47].

Educational games are assumed to motivate learners both intrinsically, for fun or challenge, and extrinsically, for external rewards. The use of gamified methods in education is often appealing to both learners and instructors because of their novelty and activating character. The use of gamified methods and games enables collaboration and competition, which motivate students [43]. Gaming in a learning context seems to positively affect overall student motivation [48]. The game-based learning method is regarded as fun, challenging, and motivating, which increases student engagement and learning efficiency [44,49].

As a summary of earlier research, the benefit of using educational games is that students can take theory into simulated real-life situations through a game. Game environments teach students how to manage connections between people and activities with integration and uncertainty. In addition to discipline-based skills, game-based learning can improve students generic skills such as decision making, problem-solving, and collaboration, all of which are competences that project managers need to practise and master.

There are also challenges and disadvantages that need to be addressed when designing and conducting game-based learning. Teachers need to consider potential or existing obstacles regarding the use and reliability of hardware and software needed in a game, together with support, resources, and skills. Game-based learning session preparation, administration, and tutoring require teachers to take on new roles in addition to lecturing. Managing the diverse preferences and proficiencies of students to ensure their interest in and motivation for learning requires attention. One of the challenges that needs to be solved when using game-based exercises is to clarify how it is connected to the subject matter taught during the course or class [50].

\subsection{Educational Game Design Principles}

Game-based learning relies on learning theories such as constructivism [11], situated learning [12], and problem-based learning [13]. Learning from educational games also utilises the principles and practices of experiential learning where concrete experiences, reflective observations, and generalisations followed by the application of learning in new situations create a continuous learning cycle [51]. Together with the mentioned learning theories, Kolb's [51] thoughts of creating knowledge through the transformation of experience can be applied in game-based learning. The aim of the educational game design is to create a learning environment where players can work individually or together in order to solve situated problems in a simulative environment. This is the first principle when designing an educational game.

Educational game design should be undertaken so that players can achieve an experience of flow in the game. Flow is defined as the subjective feeling of people where concentration and attention on activity are so high that they are forgetting time and are completely caught up in what they are experiencing [52]. Flow experience can be achieved by providing players with immediate feedback, clear goals, and suitable challenges that foster learning and positively affect learners' attitudes [53]. The second principle for designing an educational game is focusing on attraction and immersion, which will take the player into the flow state.

To create a gameful experience [54], game design elements need to be identified, such as the strategy and goal [30]. Game design elements can be divided into three hierarchical categories: components, mechanics, and dynamics. Game components such as points, levels, virtual goods, and avatars are the basic particles of games. Game mechanics refers to the interaction between player and game in the format of rules, turns, competition, feedback, and reward systems encouraging behaviour and actions that drive the game forward. Game dynamics are the highest conceptual level of the hierarchy, including constraints, emotions, progression, and the different needs of learners, which impact player motivation and engage- 
ment [55]. The third principle of successful educational game design is to recognise, plan, and implement game design elements and connect them to learning objectives.

Another viewpoint for designing a good educational game is related to educational philosophy and constructivist learning theory. Annetta [56] created a framework of six nested design elements: identity, immersion, interactivity, increasing complexity, informed teaching, and instructional level. This framework creates a path from the inner element to the outer-from player identity to instructional level, where the educational game is connected to achieving learning goals. Player identity, such as role in the game, causes immersion and a feeling of flow, which motivates learners to solve problems and proceed in the activity. Student-game and student-student interactivity create a good basis for a learning process. Increasing complexity in the game challenges students to increase their performance and keeps their motivation high. Complexity may also heighten a learning curve and present barriers to engagement, especially for new players. Informed teaching enables teachers to obtain feedback and embedded assessment information from the educational game to counsel and adjust teaching on a needs basis. Annetta [56] emphasised that having these five features in place in educational games is a prerequisite for an instructional game aligned with learning objectives.

Game design elements-game components, mechanics, and dynamics-create the foundation for educational design and use. Game mechanics determine how to play, win, or lose, while game dynamics together with player emotions create and impact desired behaviour change [57]. Educational game design can be seen as a triadic framework, where elements of play, pedagogy, and fidelity are combined and balanced to create motivating and educationally purposeful games [58]. We present here three game design element frameworks, which represent the building blocks for educational game design.

Mitgutsch and Avarado [59] identified an assessment framework of six elements of serious games that can also be used for designing educational games. Purpose connects the game to its aims and intended impact on players. Content and information focus on the validity and usefulness of the data used and shown in the game. Game mechanics involve the enablers of gameplay, such as the design of rules, goals, difficulty levels, and rewards. Fiction and narrative refer to the story that, in connection with the game's purpose, takes the player through the game or simulates a specific condition. Framing focuses on taking into account the target group of learners and their competence levels in relation to game complexity to ensure a positive experience. Aesthetics and graphics in computer games create the visualisation of all other elements and impact game usability and purpose.

The gamer rules and scenario-conceptual model (GREM) concentrates on game features, which typically contribute to providing an engaging and educational experience. It is based on situated learning theory, where the learning process is connected with activities performed in a certain context. The design model consists of two modular sub-models. The game rules model defines a layered framework, where a game is designed, starting from game mechanics and goals to reward mechanisms. The game scenario model consists of the context and virtual elements of the game, supporting services, and interaction interface layers. The idea of this design framework is to ensure that game scenarios are given enough focus in the game design face. The modularity enables the reuse of game elements when designing new games [60].

Sailer et al. [61] discussed seven typical game design elements, of which the four most relevant for gamified learning design purposes were selected. Points are typical elements of any game used for giving feedback on player actions, measuring the progress, and rewarding the player. Leaderboards can be used as motivators for competition between players because they show the player's position among other players on a ranking list. Performance graphs typically used in simulative educational games indicate players' or learners' performance development over time, targeting improvement actions. Meaningful stories can help motivate learners to understand the analogy between activities and realworld phenomena, which is also applicable when designing educational games. 


\section{Materials and Methods}

The research process of this study follows design science principles and, more specifically, action design research (ADR) as a methodological approach [62]. ADR comprises an intensive practitioner-researcher collaboration and interaction that aims to solve a current and anticipated real-life problem of the practitioners and make a strong theoretical contribution $[63,64]$. ADR typically includes stages of problem formulation: building, intervention, and evaluation; reflection and learning; and formalisation of learning. Figure 1 illustrates the research process that was applied in this study based on the ADR methodology.

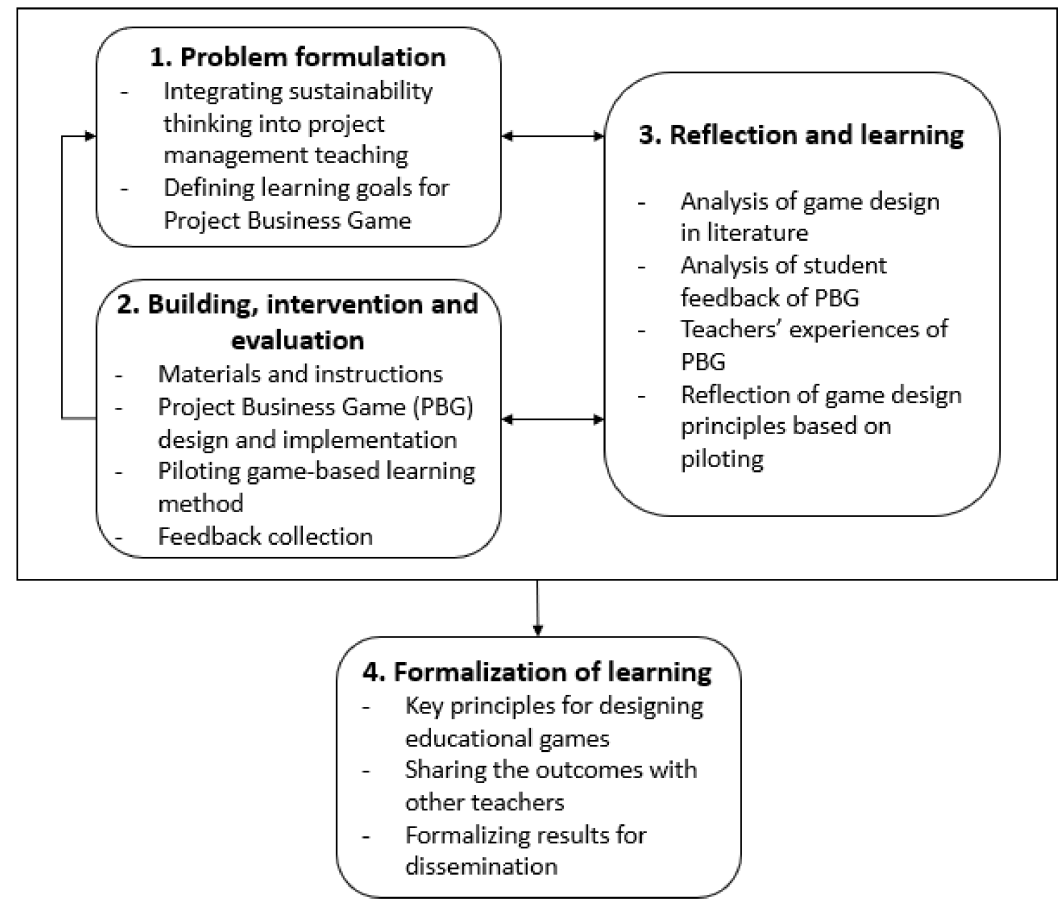

Figure 1. Action design research methodology.

\subsection{Problem Formulation}

In our case, the practitioners were higher education teachers for whose purposes the actual educational game solution was developed. The actual starting point for our research was the challenge of teaching project sustainability management in an engaging and meaningful manner for diverse students so that the relevant learning objectives would be met and the students could apply the theoretical knowledge in contexts that simulated real-life situations. The problem definition identified the need to integrate sustainability thinking into teaching the key processes of project management as a key challenge. Particular consideration was given to the project cost and uncertainty management perspective and to demonstrating their links with project sustainability-related decision making. As an outcome of the problem definition process, the following learning objectives for the game were identified, explain the basic principles related to project cost management, make informed decisions that take into account the circular economy perspective, understand the importance of stakeholder engagement and its implications for project performance, deal with various sources of uncertainty that influence project sustainability implementation, control the project and align resources to deliver the project on time and within budget, and understand the importance of project planning decisions in the execution and operations phase.

\subsection{Building, Intervention and Evaluation}

After defining the problem and developing the concept of the project sustainability management game, an actual solution was built. The solution development utilised theoretical understanding and knowledge related to educational game design and its 
design principles, as well as project sustainability management competences. Here, both the practitioner experience of the higher education teachers engaged in project sustainability management and prior theoretical research insights on project sustainability management were used. The development team included two experienced professors with extensive project management and project sustainability management teaching experience, and the project's sustainability management game solution was built on a configurable gaming platform developed within the team. The actual implementation of the digital game solution was executed by a game development company. Section 4. Project Business Game as a teaching method contains more details of the game. In addition to the actual digital game solution, preparatory materials and instructions were created during this phase.

When the game solution was ready, we proceeded to the pilot phase in February 2021. The solution was piloted with a group of European Junior Expert in Circular Studies students and implemented as part of the Business Sustainability submodule. The student group included 20 higher education students with diverse nationalities, backgrounds, and knowledge. They were provided with a short case description prior to the game that included information on the project cost, activity, and sustainability management themes of the imaginary case of 'designing and building a new production line for the separation of construction waste for recycling'. The students did not have any extensive experience in project sustainability management before attending the course.

Before playing the game, the students had taken a 1-day intensive seminar on sustainability and circular economy management in the context of projects. Their knowledge of the topic was considered to be at the same level, and the division into the student groups was random. The students played the game in groups of three or four and had around $90 \mathrm{~min}$ for the game round. After this, they prepared a post-game analysis based on a template directing their analysis focus to the evaluation of the success of their project from diverse perspectives, including the sustainability perspective, discussing the key decisions affecting their performance, analysing the risks and uncertainties related to project sustainability management, evaluating learnings related to the circular economy and sustainability thinking, and developing three key lessons from the project sustainability management point of view. These learnings were then discussed in a debriefing session in which the students were asked for feedback about the developed game solution with a separate questionnaire.

\subsection{Reflection and Learning}

The questionnaire elements were based on research on the use of educational games in the higher education sector and included the accomplishment of the set learning objectives, assessment of student engagement when playing the game, and utility of the development solution, as well as questions concerning the development of the game solution. Since student engagement improves learning, the theory of cognitive, behavioural, and emotional engagement was used as a background when designing student survey questions [65]. Cognitive engagement was measured with questions evaluating the achievement of learning goals, the relevance of the game in the learning context, and personal investment in learning. Behavioural and emotional engagement is connected to learners' participation, interactions, interest, feelings, and attitudes towards learning.

After the piloting and feedback collection phase, we proceeded to reflection and learning from the pilot. This phase included a more thorough qualitative analysis of the student feedback and teachers' observations. This analysis is reported in Section 5: Feedback and validation.

\subsection{Formalisation of Learning}

In the final stage, following ADR principles, we engaged in the process of the formalisation of learning. In our research process, we defined and elaborated key principles for designing educational games in a project sustainability management context. We are sharing the outcomes with other teachers and formalising results for dissemination to the 
larger academic community in the form of this research article. In addition, we plan to use the research results to further develop the Project Business Game.

\section{Project Business Game as a Teaching Method}

The Project Business Game (PBG) has been designed to provide an environment in which students can learn new skills, apply them in practical situations, and be given immediate feedback on their decisions and actions. It is a digital game that aims to create an active learning experience in which different elements of game-based learning are utilised to engage and motivate students. The game is highly configurable and can be easily adapted to different types of contexts and learning goals. Technical implementation of the game is based on a game engine and a separate configuration file, which can be edited to simulate and control various game scenarios.

At the core of the PBG is a simulation model, which includes a complex project task network, subcontractors, materials, and employees working on the project. There is uncertainty related to each of the core elements of the game. For example, employees may make mistakes, work has to be re-completed, work estimates may be incorrect, material deliveries do not proceed as planned, subcontractors do not work according to contracts, and customers may change their requirements. The uncertainty may also relate to external elements of the project, such as the weather, which may cause difficulties in construction works. Students may also face events such as accidents at the construction site that need to be properly managed. These events make the game more realistic, but they also bring elements of surprise and luck to the gameplay. Any of these events can be configured, taking into account the fidelity of the game experience, how they support learning, and whether they make playing the game an engaging and enjoyable experience. In Figure 2, the main game field is shown.

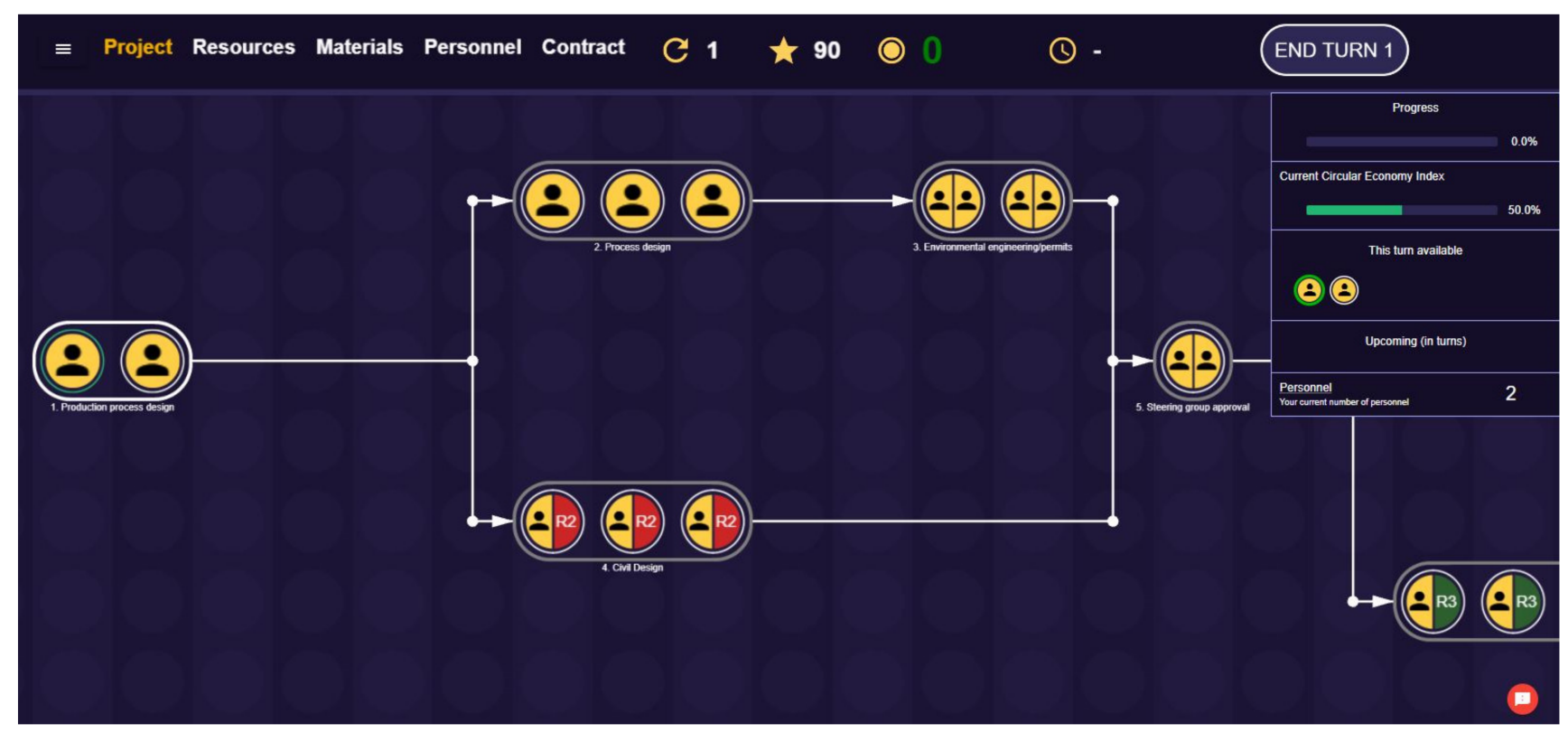

Figure 2. Project Business Game—the main view of the sustainability game.

The idea of the game is that the player proceeds through the project task network illustrated in Figure 1. The player needs to plan and prepare for coming tasks to ensure that needed resources, materials and personnel are available when needed. The player marks the activities and completes them by pressing the button 'End turn', where 'turn' simulates, for example, the time period of 1 week in real life. The player tries to accomplish a result where cost, schedule and quality of the project is optimal. In this game, the objective was to maximise the overall profitability of the investment (revenue-costs). As in real-life projects, uncertainty and decisions which need to be made during the project lifespan may 
change the game. Figure 3 shows an example of a player decision regarding stakeholder engagement, which affects the gameplay. This game event is connected to the sustainability theme and learning implications as defined in Table 1.

\section{Planning of the production process prolongs}

You have proceeded well with your plans. Would you, however, like to discuss in more detail with the different internal stakeholders on what are their requirements for this circular economy project?

On the other hand the mapping of these stakeholders' requirements may take easily two extra weeks and this way prolong your project. It is up to you to decide, whether this is a good idea or not.

Would you like to conduct a more detailed mapping of the requirements related to circular economy approach?

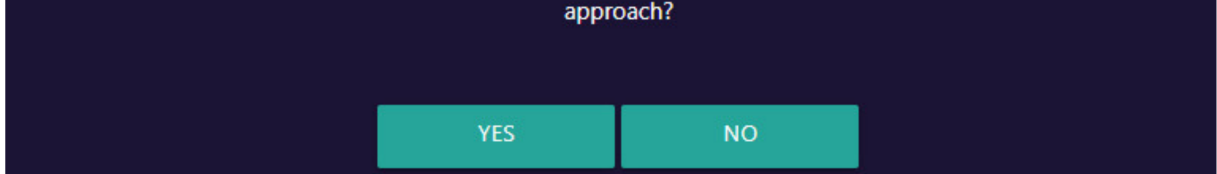

Figure 3. Project stakeholder engagement decision situation in PBG.

Table 1. Project sustainability management-related decision-making situations in the game and learning implications.

\begin{tabular}{|c|c|}
\hline $\begin{array}{l}\text { Decision-Making Situation and } \\
\text { Sustainability Theme }\end{array}$ & Sustainability Theme and Learning Implications \\
\hline $\begin{array}{l}\text { Project stakeholder engagement: the } \\
\text { student needs to make a decision during } \\
\text { the planning of the production process of } \\
\text { whether to engage more internal } \\
\text { stakeholders and map their requirements } \\
\text { in detail. This will delay the project but } \\
\text { may offer more insights into stakeholders' } \\
\text { requirements. }\end{array}$ & $\begin{array}{l}\text { The decision-making situation deals with social } \\
\text { and economic sustainability and addresses the } \\
\text { trade-off of engaging stakeholders early, which } \\
\text { requires resources and may bring complicated } \\
\text { requirements but may, on the other hand, create } \\
\text { value during the later stages of the project. } \\
\text { Following learnings related to project } \\
\text { sustainability management with regard to this } \\
\text { decision-making situation are addressed: } \\
\text { - Front-end investments in engaging } \\
\text { stakeholders may take time but support } \\
\text { value creation for stakeholders and may } \\
\text { prevent costly changes in the project later. } \\
\text { It is cheaper to map all requirements as early } \\
\text { as possible and incorporate them into the } \\
\text { project design. } \\
\text { Engaging stakeholders also ensures that they } \\
\text { feel they are a part of the project team. } \\
\text { Changes during the later stages of the project } \\
\text { may be expensive. }\end{array}$ \\
\hline
\end{tabular}


Table 1. Cont.

Decision-Making Situation and Sustainability Theme

Supplier collaboration and supplier integration into the design process: the student needs to make a decision about whether to include automation and production line suppliers in the design process. This will prolong the project but may offer more insights into stakeholders' requirements.

Innovation investments: the student needs to decide whether to invest more in exploring the potential technological innovations that could improve the sustainability of the end product (reduced waste disposal costs and better yield) but are uncertain.

\section{Sustainability Theme and Learning Implications}

The decision-making situation deals with economic sustainability and addresses the challenge of engaging suppliers early. Following learnings related to project sustainability management with regard to this decision-making situation are addressed:

- $\quad$ Engaging suppliers and working collaboratively with them increases trust and commitment and may also bring relevant ideas during the design stage of the project (decreases changes and may also support efficient decision making if problems occur).

- The engagement of suppliers takes time and resources, so investments in collaboration efforts with those suppliers with whom one plans to work in the future and who are strategic for one's business are most important.

The decision-making situation deals with economic sustainability and addresses the challenge of making uncertain innovation-related decisions in the project design phase. The following learnings related to project sustainability management with regard to this decision-making situation are addressed:

- Investments in innovation processes may be risky in projects, as the investigations may take valuable time and may turn out to be invaluable or too costly. They can also raise the uncertainty level of the project.

- $\quad$ On the other hand, one may gain significant benefits from innovations/better ways of working, and they may equip the project with new capabilities and knowledge that can be utilised in forthcoming projects.

- There is always a trade-off on how much one can invest in exploring the different options during the design stage of the project due to time pressure. 
Table 1. Cont.

Decision-Making Situation and Sustainability Theme

SIA and external stakeholder engagement: the student needs to make a decision about whether to conduct an SIA, which is not required by law in this case. It requires financial investment and will delay the project by 1 week. On the other hand, it is reported that there is potential unrest among the local people.

\section{Sustainability Theme and Learning Implications}

The decision-making situation deals with social sustainability, SIA, and the trade-offs of engaging external stakeholders in the project. The following lessons related to project sustainability management with regard to this decision-making situation are addressed:

- The social implications of projects are typically significant, and one should not dismiss or neglect the evaluation of the social implications (e.g., in the form of SIA, even though it is not required by law).

- $\quad$ SIA may offer the project valuable information on the external environment of the project and support the project in receiving a social licence to operate.

- It depends on the project context and the optimal investment in the SIA process.

The decision-making situation deals with economic and environmental sustainability related to responsible supplier selection in projects and the need to balance between the direct economic implications and potential long-term effects, as well as considering the sustainability strategies of the project participants when making decisions. The following learnings related to project sustainability management with regard to this decision-making situation are addressed:

- When supplier selection decisions are made in a project, a variety of factors need to be taken into account. In this case, the case company emphasises sustainability thinking and wants to support suppliers with ambitious sustainability goals.

- $\quad$ There are always trade-offs: the certified supplier is more expensive and does not have previous experience of working together, which increases the level of uncertainty.

- On the other hand, one should consider the beneficial impact of a more sustainable supplier on the operation costs (lifecycle costs) and the future potential of the supplier. 
Table 1. Cont.

Decision-Making Situation and
Sustainability Theme

HSEQ and occupational accident: a severe occupational accident takes place during the construction phase, and the student is faced with the decision of whether to conduct a more detailed investigation into it, which will delay the project. with the energy efficiency of the production line, quality level, and sustainability of the new requirements at a late stage of the a decision about whether to incorporate late phase of the design process.
Quality and sustainability of the end

\section{Sustainability Theme and Learning Implications}

The decision-making situation deals with economic and environmental sustainability related to project product-related decisions and life cycle evaluation. The following learnings related to project sustainability management with regard to this decision-making situation are addressed:

- The decisions in the design stage and the decisions concerning the involvement of stakeholders significantly influence the project costs (both during the execution phase and then in the operational life cycle).

- $\quad$ Product-related decisions in the design process decrease the amount of waste and improve energy efficiency, and one should carefully consider the life cycle costs related to project design decisions.

The decision-making situation deals with economic and social sustainability and focuses on the trade-offs between safety and costs. Following learnings related to project sustainability management with regard to this decision-making situation are addressed:

- Safety-related decisions should always be taken seriously and prioritised.

- $\quad$ Safety is a key result area in project governance systems.

- Prior safety problems are indicators of the vulnerability of the project system.

The decision-making situation deals with economic and environmental sustainability and addresses the trade-offs between risk management costs and the potential gains achieved through them. The following learnings related to project sustainability management with regard to this decision-making situation are addressed:

Poisonous substances from the production process, which could be either a nonrecurring outcome of maintenance work or a sign of a process failure: the student needs to make a decision whether to invest in process consulting or to trust their instinct that the process works fine.
- One should take into account the risk strategy of the organisation when making risk management decisions.

- Environmental risks can pose serious threats to the project and threaten its viability and the social licence to operate.

- Human decision-making biases may lead to situations where early warning signs of potential problems are dismissed, and optimism bias prevails.

The Project Business Game is a single-player game, but players may form a group that plays the game together. The latter emphasises the sociocultural aspect of the game in which students interact and learn from each other. In gameplay, the game goal is related to the success of the project, which may be related to time, cost, and quality, or other features such as meeting sustainability targets set for the project. During the game, students can compare their performance against defined objectives, and they can also see the performance of other players. This competitive element is important for some students, 
and others may be more motivated by the complexity of the game and achieving mastery of the topic.

In addition to the game, all materials required to prepare for the game and results analysis for students and teachers are included. This integrated package of materials is defined as a learning solution. The design of a learning solution starts by defining learning goals and student groups who are using games as a learning tool. Pre-game materials provide students with an adequate theoretical background for the topic and enable them to prepare for the game session. During the game session, they apply their knowledge to practical game situations, and the game then provides them with a shared learning experience that can be used in the debriefing session, focusing on key learnings from the game.

The incorporation of project sustainability management thinking into the game started with the definition of the learning goals and themes related to project sustainability management. Based on the insights of the teachers and prior theoretical aspects, we decided to focus on the following themes highlighted in project sustainability teaching: project stakeholder engagement including both internal and external stakeholders (social sustainability), the role of SIA in projects (social sustainability), sustainable supplier selection and supplier collaboration (business, social, and ecological sustainability), project innovation management (business sustainability), the impact of early design-related decisions on project product sustainability, the trade-offs between project cost management and long-term sustainability and quality, safety- and HSEQ-related decision making, and the role of circular economy thinking, reputation, and image in project sustainability management. After identifying the relevant themes, our project game design included the development of the different decision-making situations and events related to these themes and determining their impact on actual project progress.

We generated various events and decision-making situations related to the themes, including decision making on whether to invest in the SIA, which would cause some additional costs and delay the project but proved to be beneficial for the project during the execution stage as it would calm the unrest among locals concerning the project. The planned decision-making situations related to the different themes are presented in Table 1. We also designed a particular sustainability index that was visible for the players throughout the game and related to the profitability of their investment through specific logic: if the students were able to meet different, specified index levels (starting point 50), their company received sustainability certification and generated higher profits during the production line operations. The overall aim of the game was to maximise revenue (sales investment costs) generated by their production line, which was operating 5 years after the start-up.

\section{Feedback and Validation}

Student feedback on the PBG experience was collected with a survey. Fifteen students answered the questionnaire after the class. Most of them (73\%) reported having no experience working as a project manager, project coordinator, or similar role, and $27 \%$ of the students had project management experience of less than 2 years. Students were asked to estimate how extensively they had played computer games, and in another question, their experience of using educational games or simulations was evaluated. The results indicated that the students had quite a lot of experience with computer games in general, and they were also familiar with educational games and simulations.

\subsection{Project Game's Effect on Achieving Learning Goals}

The effect of the project game on learning outcomes was examined using six statements composed of the learning goals of the course. Students evaluated whether the project game had increased their ability and competence to deal with learning topics that were taught in earlier lectures and other learning materials. Students used the scale of five categories, strongly disagree (1) to strongly agree (5), to answer statements such as 'The game increased 
my ability to explain the basic principles related to project cost management'. The neutral category was defined as 'Neither agree nor disagree'.

The quantitative findings of the survey report are shown in Table 2. Students reported agreeing or strongly agreeing that playing the project game increased their ability to achieve all learning goals. The overall student satisfaction was high; only one student felt that the game did not increase their ability to make informed decisions that took into account the circular economy perspective.

Table 2. Students' responses on the project game affect achieving learning goals $(n=15)$.

\begin{tabular}{|c|c|c|c|c|c|c|c|}
\hline $\begin{array}{c}\text { The Project Game Increased } \\
\text { My Ability to: }\end{array}$ & $\begin{array}{l}\text { Strongly } \\
\text { Disagree }\end{array}$ & Disagree & Neutral & Agree & $\begin{array}{l}\text { Strongly } \\
\text { Agree }\end{array}$ & Average & Median \\
\hline $\begin{array}{l}\text { 1. Explain the basic principles } \\
\text { related to project cost } \\
\text { management. }\end{array}$ & $0 \%$ & $0 \%$ & $0 \%$ & $80 \%$ & $20 \%$ & 4.2 & 4 \\
\hline $\begin{array}{l}\text { 2. Make informed decisions that } \\
\text { take into account the circular } \\
\text { economy perspective. }\end{array}$ & $0 \%$ & $7 \%$ & $7 \%$ & $53 \%$ & $33 \%$ & 4.13 & 4 \\
\hline $\begin{array}{l}\text { 3. Understand the importance } \\
\text { of stakeholder engagement and } \\
\text { its implications for project } \\
\text { performance. }\end{array}$ & $0 \%$ & $0 \%$ & $20 \%$ & $40 \%$ & $40 \%$ & 4.2 & 4 \\
\hline $\begin{array}{l}\text { 4. Deal with various sources of } \\
\text { uncertainty (e.g., weather risk, } \\
\text { safety, quality, and } \\
\text { sustainability-related problems) } \\
\text { that influence project } \\
\text { implementation. }\end{array}$ & $0 \%$ & $0 \%$ & $13 \%$ & $54 \%$ & $33 \%$ & 4.2 & 4 \\
\hline $\begin{array}{l}\text { 5. Control the project and align } \\
\text { resources to deliver the project } \\
\text { on time and within budget. }\end{array}$ & $0 \%$ & $0 \%$ & $20 \%$ & $53 \%$ & $27 \%$ & 4.07 & 4 \\
\hline $\begin{array}{l}\text { 6. Understand the importance } \\
\text { of the project planning } \\
\text { decisions in the execution and } \\
\text { operations phase. }\end{array}$ & $0 \%$ & $0 \%$ & $7 \%$ & $53 \%$ & $40 \%$ & 4.33 & 4 \\
\hline
\end{tabular}

Teachers experiences resonate with student feedback. The game solution and debriefing supported the students in internalising the complex and even paradoxical issues related to project sustainability management as well as helped them to experiment with their learnings in practice. The learning solution supported the illustration of challenging issues related to project sustainability management. The debriefing session was highly important in discussing the learnings further with the students. Here, the role of a facilitator who is very familiar with the game and its logic is very important.

\subsection{The Project Game as a Learning Experience}

Students' satisfaction regarding suitability, motivation, challenge, and attitude was measured. The quantitative results of their answers are presented in Table 3. Overall satisfaction with the project game as a learning method was very positive; only a few negative answers were received. We point out some observations from the report that are relevant from the case study perspective. 
Table 3. Students' perceptions of the project game as a learning experience $(n=15)$.

\begin{tabular}{|c|c|c|c|c|c|c|c|}
\hline Experience Statements & $\begin{array}{l}\text { Strongly } \\
\text { Disagree }\end{array}$ & Disagree & Neutral & Agree & $\begin{array}{c}\text { Strongly } \\
\text { Agree }\end{array}$ & Average & Median \\
\hline $\begin{array}{l}\text { 1. I understand what kind of real-life } \\
\text { situations the game simulated. }\end{array}$ & $0 \%$ & $0 \%$ & $7 \%$ & $80 \%$ & $13 \%$ & 4.07 & 4 \\
\hline $\begin{array}{l}\text { 2. The game was relevant and useful } \\
\text { addition to the other learning materials } \\
\text { and methods. }\end{array}$ & $0 \%$ & $0 \%$ & $13 \%$ & $60 \%$ & $27 \%$ & 4.13 & 4 \\
\hline $\begin{array}{l}\text { 3. I could apply the theory that was } \\
\text { taught in this course. }\end{array}$ & $0 \%$ & $0 \%$ & $13 \%$ & $73 \%$ & $13 \%$ & 4 & 4 \\
\hline 4. I felt like learning. & $7 \%$ & $0 \%$ & $7 \%$ & $53 \%$ & $33 \%$ & 4.07 & 4 \\
\hline $\begin{array}{l}\text { 5. The game increased my interest in } \\
\text { the learning subject. }\end{array}$ & $0 \%$ & $0 \%$ & $7 \%$ & $46 \%$ & $47 \%$ & 4.4 & 4 \\
\hline $\begin{array}{l}\text { 6. The game content and flow captured } \\
\text { my attention. }\end{array}$ & $0 \%$ & $0 \%$ & $13 \%$ & $40 \%$ & $47 \%$ & 4.33 & 4 \\
\hline $\begin{array}{l}\text { 7. The game boosted my motivation } \\
\text { into learning of project management. }\end{array}$ & $0 \%$ & $0 \%$ & $20 \%$ & $40 \%$ & $40 \%$ & 4.2 & 4 \\
\hline $\begin{array}{l}\text { 8. My skills, focus, and effort } \\
\text { contributed to the game results. }\end{array}$ & $0 \%$ & $0 \%$ & $7 \%$ & $73 \%$ & $20 \%$ & 4.13 & 4 \\
\hline $\begin{array}{l}\text { 9. There was enough challenge and } \\
\text { complexity in the game. }\end{array}$ & $0 \%$ & $0 \%$ & $27 \%$ & $53 \%$ & $20 \%$ & 3.93 & 4 \\
\hline 10. Playing the game was easy for me. & $0 \%$ & $27 \%$ & $27 \%$ & $40 \%$ & $7 \%$ & 3.27 & 3 \\
\hline $\begin{array}{l}\text { 11. Teamwork positively affected the } \\
\text { game results. }\end{array}$ & $0 \%$ & $7 \%$ & $13 \%$ & $40 \%$ & $40 \%$ & 4.13 & 4 \\
\hline $\begin{array}{l}\text { 12. These kind of gamified learning } \\
\text { methods support online teaching. }\end{array}$ & $0 \%$ & $0 \%$ & $0 \%$ & $53 \%$ & $47 \%$ & 4.47 & 4 \\
\hline $\begin{array}{l}\text { 13. Based on my experience, these kind } \\
\text { of games are useful for learning. }\end{array}$ & $0 \%$ & $0 \%$ & $0 \%$ & $67 \%$ & $33 \%$ & 4.33 & 4 \\
\hline $\begin{array}{l}\text { 14. I enjoyed participating in this } \\
\text { gamified learning session. }\end{array}$ & $0 \%$ & $0 \%$ & $7 \%$ & $40 \%$ & $53 \%$ & 4.47 & 5 \\
\hline $\begin{array}{l}\text { 15. In general, my attitude towards } \\
\text { gamified learning is positive. }\end{array}$ & $0 \%$ & $0 \%$ & $0 \%$ & $60 \%$ & $40 \%$ & 4.4 & 4 \\
\hline
\end{tabular}

According to the first four statements (1-4) of this part of the survey, students understood the connection between theory and the simulation of the project environment created by the project game and felt they had learned effectively. Interest and motivation were rated as high (5-8). The game was considered challenging enough (9). Some students felt the game was difficult for them to play: $27 \%$ of the answers indicated that the project game was not easy, and $27 \%$ gave a neutral response (10). The project game was played in teams of students in this exercise. A total of $80 \%$ of students thought that teamwork (11) positively affected the game results, while one student disagreed with that.

The last four statements (12-15) measured attitudes towards gamified learning methods in general. There was almost $100 \%$ agreement among students that educational games can be utilised in online teaching. The majority of respondents said that they had enjoyed participating in this particular gamified learning session; only one student had a neutral opinion (14). Attitudes towards gamified learning were very positive among these students. In summary, the students felt that the use of project games in the circular economy project management education context was a useful and convenient learning experience.

We also conducted a course feedback questionnaire of this specific module about students' overall satisfaction with teaching methods, materials, and learning during the module. The average student satisfaction was $4.5 / 5$. Open feedback from students is also aligned with student satisfaction results but indicates that there is still room for improvement:

- 'The part related to the change of requirement was a little bit cloudy, My team has some difficulties to understand it. Maybe it was just us.'

- 'It is very nice as it shows the quick consequences of your decision which kind of build your mind in terms of project management.' 
- 'Show more data; numbers, percentages in order to calibrate better decision, especially in what field you should invest more in. For example, the circular economy index: what factors influence it? Have infos about the game itself readily available: example what happens if you train a worker, advantages etc (e.g., pop up window when you leave the pointer on the personnel word).'

- 'Larger titles for better visibility, scale of time (weeks) under or below the game bubbles. Would be very effective for learning to have a feedback from the game results pointing out which decisions were made 'wrongly' by the players and explanations 'why'.'

From a teacher's perspective, the learning solution is simple, but to ensure a positive learning experience, enough time should be invested in presenting the game mechanics to the students. Students' attitudes towards gaming seemed positive, and they were engaged in the gameplay.

\section{Discussion}

In game-based learning, games are used to create an active learning experience to teach knowledge and skills [36]. Students can apply theoretical knowledge and receive immediate feedback on their actions in a game-based learning environment. We designed a learning solution with specific learning goals derived from the project sustainability management literature. The game addresses key themes identified in the literature, such as the importance of making decisions in the project design face [19], the inclusion of internal and external stakeholders in the decision-making processes [2], and understanding of how decisions during the project influence the sustainability of the project product [25]. Decisions related to sustainability have an impact on project cost, schedule, and overall value creation, which emphasises that sustainability is an integrated part of all project management processes. This goal is well-aligned with research suggesting that including a sustainability perspective in project management decisions positively affects project success [8].

Teaching sustainability management in higher education institutions with innovative digital tools plays a fundamental role in the transition toward sustainable societies. Suitable game design elements play a significant role in facilitating learning [66,67]. According to the user survey and observations, the use of the PBG as a game-based learning method in project sustainability management education supports the achievement of the learning goals. This finding is in line with research on education gamification, where the achievement of learning goals is seen to be supported by activating exercises that require applying the theory in practice [43-45]. Students indicated an understanding of how the developed game simulated the real-life phenomena of managing project costs, resources, stakeholders, and uncertainty with a circular economy project example built into the game. Despite the fact that a simulation game is always a simplified and artificial model of reality, students indicated that the game was a valuable addition to other learning materials of the course, providing them with the possibility to apply the theory in practice with the game exercise. The majority of the students agreed with the statement 'I felt like learning'. The game design process and the use of the game as a learning method can therefore be considered successful.

Playing the PBG requires making informed decisions about which consequences can easily be seen when proceeding in the game. According to earlier research, educational games positively affect decision-making performance [42]. In addition, challenge and engagement in the game increase learning [47]. To succeed and obtain high scores in the game requires thorough planning of activities to avoid missing critical resources or losing money, just as in real-life projects. Despite meticulous preparation, something unexpected can and will happen. The game design includes challenges and surprises the students need to react to, which prepares and teaches them to solve problems, change or adjust existing plans, and develop their critical thinking skills. All of these skills are essential for future project managers.

The interest and motivation of students are usually increased in game-based learning because it is fun, exciting, and inspiring. Students' interest and motivation were well 
captured with the PBG exercise according to a questionnaire of game experiences and overall course feedback. Collaboration with team members was considered beneficial. Interest in the learning subject requires attention and causes interaction with the course content, which improves learning. These observations lend support to prior research findings $[43,48]$.

Berggren and Söderlund [28] emphasise the importance of social learning in project management education, enabling knowledge co-production. Students felt that working as a team improved the game results. Teamwork also supports the development of generic skills, such as collaboration and communication skills, which are relevant for project managers regardless of the field. Debriefing sessions are considered important and included in suggested design principles in game-based learning because they bring together students and teachers in a forum where the instructor's professional knowledge and students' observations, experiences, and thoughts can be shared and discussed.

Overall, the attitude towards gamified learning was positive. Student satisfaction with the game-based learning method, in this case, can be evaluated as high because, in addition to other questions measuring favourable experiences, almost all students agreed with the statement 'I enjoyed participating in this gamified learning session'. This is especially encouraging when further developing learning solutions, including the PBG. There seems to be a shortage of this kind of highly stimulating and activating learning method in project management higher education.

\subsection{Practical Implications}

Our results suggest that game-based learning can be used to improve learning outcomes. Based on our results, the PBG is highly suitable for teaching project sustainability in an engaging and effective manner. It facilitates the incorporation of project sustainability thinking and management as an integral and harmonised part of project management teaching. In game-based learning, students can experience situations that are most relevant to learn the topic [68].

From the game design literature, we would like to highlight the importance of defining learning goals, which are supported by situational problem-solving activities and experiential learning [51]. Flow experience during games improves learning results and positively affects learners' attitudes [52,53,56]. Therefore, it is important to design and create a game that is fascinating and that challenges the player in a reasonable way. In order to create a gameful experience for learning purposes, game design elements such as game components (points, levels, virtual goods), mechanics (rules, turns, feedback), and dynamics (constraints, emotions, progression) need to be identified [34,54,55,57]. Game design elements are the foundation for game design and use, where elements of play, pedagogy, and fidelity are combined for a motivational and educationally purposeful game [58].

In the following section, we present key design principles based on this research, which should be taken into account when designing educational games:

- Start the design with learning goals that are based on existing knowledge in the field.

- An educational game is only one part of the learning solution, which aims to provide students with new skills and knowledge as defined in learning goals. Consider which activities students are expected to learn during the learning session and which materials are required to support preparation for the learning session.

- Educational games do not need to be realistic representations of real projects or phenomena, but realism can support meeting learning goals. Meaningful stories and narrative case descriptions will help students understand the connection between game activities and real-world situations.

- Design and apply game components, mechanics, and dynamics to create a gameful experience, engaging game, and learning environment in which students can individually or as a team make decisions and solve problems related to learning goals. 
- Debriefing and student reflection are important parts of game-based learning to share and analyse what has been learned with peers and the instructor.

These design principles can be applied when creating educational games for project sustainability education or in general project management and for integrating available educational games into existing courses to create learning solutions. We also suggest that these design principles are not specific to project sustainability education but can be applied to other educational game design contexts as well.

\subsection{Limitations and Further Research}

In this research, we applied the Project Business Game in the context of project sustainability education. We incorporated the learning goals of project sustainability management into a game-based learning solution where design principles were applied to tailor a suitable game. The results are based on a single educational game solution, which naturally limits the generalisability of the findings. The limitation of this study is the small number of students who participated, but our findings are well aligned with previous research on game-based learning. Further research on the effectiveness of gamebased learning in project sustainability education should be completed with multiple student groups with different types of students to better understand the influence on learning outcomes and adjustment needs. For example, student background, social skills, prior knowledge of learning subject and experience of games may influence learning outcomes. There are also known challenges, disadvantages, and limitations regarding the use of game-based learning methods, but they were not observed or discussed in this study. Our perspective was mainly on the student experience, but there is also a need to better understand the use of educational games from the teacher's perspective. Teachers' experiences, expectations, and required skills for using game-based learning solutions would be interesting avenues for further studies.

Author Contributions: Conceptualisation, E.J.; methodology, K.A. and E.J; Section 4, K.A. and J.K.; data collection and analysis, E.J.; writing-original draft preparation, E.J.; writing-review and editing E.J., K.A. and J.K.; supervision, K.A.; funding acquisition, J.K. All authors have read and agreed to the published version of the manuscript.

Funding: This research was funded by Business Finland, grant number 1648/31/2020 and the Ministry of Education Finland, grant number OKM/131/523/2019.

Institutional Review Board Statement: Not applicable.

Informed Consent Statement: Informed consent was obtained from all subjects involved in the study.

Data Availability Statement: Not applicable.

Conflicts of Interest: The authors declare no conflict of interest.

\section{References}

1. Labuschagne, C.; Brent, A.C. Sustainable project life cycle management: The need to integrate life cycles in the manufacturing sector. Int. J. Proj. Manag. 2005, 23, 159-168. [CrossRef]

2. Silvius, A.J.G.; Schipper, R. Developing a maturity model for assessing sustainable project management. J. Mod. Proj. Manag. 2015, 3, 16-27.

3. Stanitsas, M.; Kirytopoulos, K.; Leopoulos, V. Integrating sustainability indicators into project management: The case of construction industry. J. Clean. Prod. 2021, 279, 123774. [CrossRef]

4. Banihashemi, S.; Hosseini, M.R.; Golizadeh, H.; Sankaran, S. Critical success factors (CSFs) for integration of sustainability into construction project management: Practices in developing countries. Int. J. Proj. Manag. 2017, 35, 1103-1119. [CrossRef]

5. Khalifeh, A.; Farrell, P.; Alrousan, M.; Alwardat, S.; Faisal, M. Incorporating sustainability into software projects: A conceptual framework. Int. J. Manag. Proj. Bus. 2020, 13, 1339-1361. [CrossRef]

6. Calero, C.; Piattini, M. Puzzling out Software Sustainability. Sustain. Comput. Inform. Syst. 2017, 16, 117-124. [CrossRef]

7. Marnewick, C. Information system project's sustainability capability levels. Int. J. Proj. Manag. 2017, 35, 1151-1166. [CrossRef]

8. Carvalho, M.M.; Rabechini, R. Can project sustainability management impact project success? An empirical study applying a contingent approach. Int. J. Proj. Manag. 2017, 35, 1120-1132. [CrossRef] 
9. Khalifeh, A.; Farrell, P.; Al-edenat, M. The impact of project sustainability management (PSM) on project success. J. Manag. Dev. 2019, 39, 453-474. [CrossRef]

10. Kolb, A.Y.; Kolb, D.A. Learning Styles and Learning Spaces: Enhancing Experiential Learning in Higher Education. Acad. Manag. Learn. Educ. 2005, 4, 193-212. [CrossRef]

11. Phillips, D.C. The good, the bad, and the ugly: The many faces of constructivism. Educ. Res. 1995, 24, 5-12. [CrossRef]

12. Lave, E.; Wanger, J. Situated Learning: Legitimate Peripheral Participation; Cambridge University Press: Cambridge, UK, 1991.

13. Savin-Baden, M.; Major, C.H. Foundations of Problem-Based Learning; McGraw-Hill Education: London, UK, 2004.

14. Vandaele, N.J.; Decouttere, C.J. Sustainable R\&D portfolio assessment. Decis. Support Syst. 2013, 54, 1521-1532. [CrossRef]

15. Martens, M.L.; Carvalho, M.M. Key factors of sustainability in project management context: A survey exploring the project managers' perspective. Int. J. Proj. Manag. 2017, 35, 1084-1102. [CrossRef]

16. Sánchez, M.A. Integrating sustainability issues into project management. J. Clean. Prod. 2015, 96, 319-330. [CrossRef]

17. Silvius, G. Sustainability as a new school of thought in project management. J. Clean. Prod. 2017, 166, 1479-1493. [CrossRef]

18. Eskerod, P.; Huemann, M. Sustainable development and project stakeholder management: What standards say. Int. J. Manag. Proj. Bus. 2013, 6, 36-50. [CrossRef]

19. Aarseth, W.; Ahola, T.; Aaltonen, K.; Økland, A.; Andersen, B. Project sustainability strategies: A systematic literature review. Int. J. Proj. Manag. 2017, 35, 1071-1083. [CrossRef]

20. Esteves, A.M.; Franks, D.; Vanclay, F. Social impact assessment: The state of the art. Impact Assess. Proj. Apprais. 2012, 30, 34-42. [CrossRef]

21. Liu, C.; Zhang, K.; Zhang, J. Sustainable utilization of regional water resources: Experiences from the Hai Hua ecological industry pilot zone (HHEIPZ) Project in China. J. Clean. Prod. 2010, 18, 447-453. [CrossRef]

22. Shi, Q.; Zuo, J.; Zillante, G. Exploring the management of sustainable construction at the programme level: A Chinese case study. Constr. Manag. Econ. 2012, 30, 425-440. [CrossRef]

23. Davies, A.; Macaulay, S.; Debarro, T.; Thurston, M. Making innovation happen in a megaproject: London's crossrail suburban railway system. Proj. Manag. J. 2014, 45, 25-37. [CrossRef]

24. Reiman, T.; Rollenhagen, C. Does the concept of safety culture help or hinder systems thinking in safety? Accid. Anal. Prev. 2014, 68, 5-15. [CrossRef]

25. Toljaga-Nikolić, D.; Todorović, M.; Dobrota, M.; Obradović, T.; Obradović, V. Project management and sustainability: Playing trick or treat with the planet. Sustainability 2020, 12, 8619. [CrossRef]

26. International Project Management Association. Individual Competence Baseline version 4. Available online: www.ipma.world/ individuals/standard/ (accessed on 19 May 2021).

27. Wiek, A.; Withycombe, L.; Redman, C.L. Key competencies in sustainability: A reference framework for academic program development. Sustain. Sci. 2011, 6, 203-218. [CrossRef]

28. Silvius, A.J.G.; Schipper, R.P.J. Sustainability in project management competencies: Analyzing the competence gap of project managers. J. Hum. Resour. Sustain. Stud. 2014, 2, 40-58. [CrossRef]

29. Berggren, C.; Söderlund, J. Rethinking project management education: Social twists and knowledge co-production. Int. J. Proj. Manag. 2008, 26, 286-296. [CrossRef]

30. Deterding, S.; Dixon, D.; Khaled, R.; Nacke, L. From Game Design Elements to Gamefulness: Defining ‘Gamification'. In Proceedings of the 15th International Academic MindTrek Conference: Envisioning Future Media Environments, Tampere, Finland, 28-30 September 2011; pp. 9-15.

31. Zichermann, G.; Cunningham, C. Gamification by Design: Implementing Game Mechanics in Web and Mobile Apps; O’Reilly Media Inc.: Sebastopol, CA, USA, 2011.

32. Huotari, K.; Hamari, J. A definition for gamification: Anchoring gamification in the service marketing literature. Electron. Mark. 2017, 27, 21-31. [CrossRef]

33. Simões, J.; Aguiar, A. A social gamification framework for a K-6 learning platform. Comput. Hum. Behav. 2013, 29, 345-353. [CrossRef]

34. Kapp, K.M.; Lucas, B.; Mesch, R. The Gamification of Learning and Instruction Fieldbook: Ideas into Practice; Wiley: San Francisco, CA, USA, 2014.

35. Landers, R.N. Developing a theory of gamified learning. Simul. Gaming 2014, 45, 752-768. [CrossRef]

36. Shaffer, D.W.; Squire, K.R.; Halverson, R.; Gee, J.P. Video games and the future of learning. Phi Delta Kappan 2005, 87, $105-111$. [CrossRef]

37. Sauve, L.; Renaud, L.; Kaufman, D.; Marquis, J.S. Distinguishing between games and simulation: A systematic review. Educ. Technol. Soc. 2007, 10, 247-256.

38. De Freitas, S. Are games effective learning tools? A review of educational games. Educ. Technol. Soc. 2018, 21, 74-84.

39. Plass, J.L.; Homer, B.D.; Kinzer, C.K. Foundations of game-based learning. Educ. Psychol. 2015, 50, 258-283. [CrossRef]

40. Dicheva, D.; Dichev, C.; Agre, G.; Angelova, G. Gamification in Education: A Systematic Mapping Study. Technol. Soc. 2015, 18, 75-88.

41. Subhash, S.; Cudney, E.A. Gamified learning in higher education: A systematic review of the literature. Comput. Hum. Behav. 2018, 87, 192-206. [CrossRef] 
42. Rumeser, D.; Emsley, M. Can serious games improve project management decision making under complexity? Proj. Manag. J. 2019, 50, 23-39. [CrossRef]

43. Antonaci, A.; Dagnino, F.M.; Ott, M.; Bellotti, F.; Berta, R.; de Gloria, A.; Lavagnino, E.; Romero, M.; Usart, M.; Mayer, I. A gamified collaborative course in entrepreneurship: Focus on objectives and tools. Comput. Hum. Behav. 2015, 51, 1276-1283. [CrossRef]

44. Barbosa, M.W.; de Ávila Rodrigues, C. Project portfolio management teaching: Contributions of a gamified approach. Int. J. Manag. Educ. 2020, 18, 100388. [CrossRef]

45. Hamzeh, F.; Theokaris, C.; Rouhana, C.; Abbas, Y. Application of hands-on simulation games to improve classroom experience. Eur. J. Eng. Educ. 2017, 42, 471-481. [CrossRef]

46. Abdul Jabbar, A.I.; Felicia, P. Gameplay engagement and learning in game-based learning. Rev. Educ. Res. 2015, 85, 740-779. [CrossRef]

47. Hamari, J.; Shernoff, D.J.; Rowe, E.; Coller, B.; Asbell-Clarke, J.; Edwards, T. Challenging games help students learn: An empirical study on engagement, flow and immersion in game-based learning. Comput. Hum. Behav. 2016, 54, 170-179. [CrossRef]

48. Day-Black, C.; Merrill, E.; Konzelman, L.; Williams, T.; Hart, N. Gamification: An innovative teaching-learning strategy for the digital nursing student in community health nursing course. ABNF J. 2015, 26, 90-93.

49. Mathrani, A.; Christian, S.; Ponder-Sutton, A. PlayIT: Game Based Learning Approach for Teaching Programming Concepts. Int. Forum Educ. Technol. Soc. 2016, 19, 5-17.

50. Berg Marklund, B.; Alkind Taylor, A.-S. Educational games in practice: The challenges involved in conducting a game-based curriculum. Electron. J. E-Learn. 2012, 14, 122-135.

51. Kolb, D.A. Experiential Learning: Experience as the Source of Learning and Development; Prentice-Hall: Englewood Cliffs, NJ, USA, 1984.

52. Csikszentmihalyi, M.; Abuhamdeh, S.; Nakamura, J. Flow and the Foundations of Positive Psychology; Springer: Dordrecht, The Netherlands, 2014. [CrossRef]

53. Kiili, K. Digital game-based learning: Towards an experiential gaming model. Internet High. Educ. 2005, 8, 13-24. [CrossRef]

54. Salen, K.; Zimmerman, E. Rules of Play: Game Design Fundamentals; The MIT Press: Cambridge, MA, USA, 2004.

55. Werbach, K.; Hunter, D. For the Win: How Game Thinking Can Revolutionize Your Business; Wharton Digital Press: Philadelphia, PA, USA, 2012.

56. Annetta, L.A. The 'I's' have it: A framework for serious educational game design. Rev. Gen. Psychol. 2010, 14, 105-112. [CrossRef]

57. Robson, K.; Plangger, K.; Kietzmann, J.H.; McCarthy, I.; Pitt, L. Is it all a game? Understanding the principles of gamification. Bus. Horiz. 2015, 58, 411-420. [CrossRef]

58. Rooney, P. A theoretical framework for serious game design: Exploring pedagogy, play and fidelity and their implications for the design process. Int. J. Game-Based Learn. 2012, 2, 41-60. [CrossRef]

59. Mitgutsch, K.; Alvarado, N. Purposeful by Design. A Serious Game Design Assessment Model. In Proceedings of the International Conference on the Foundations of Digital Games, New York, NY, USA, 29 May-1 June 2012; pp. 121-128.

60. Zarraonandia, T.; Diaz, P.; Aedo, I.; Ruiz, M.R. Designing educational games through a conceptual model based on rules and scenarios. Multimed. Tools Appl. 2015, 74, 4535-4559. [CrossRef]

61. Sailer, M.; Hense, J.U.; Mayr, S.K.; Mandl, H. How gamification motivates: An experimental study of the effects of specific game design elements on psychological need satisfaction. Comput. Hum. Behav. 2017, 69, 371-380. [CrossRef]

62. Sein, M.K.; Henfridsson, O.; Purao, S.; Rossi, M.; Lindgren, R. Action design research. MIS Q.: Manag. Inf. Syst. 2011, 35, 37-56. [CrossRef]

63. Benbasat, I.; Zmud, R.W. The identity crisis within the IS discipline: Defining and communicating the discipline's core properties. MIS Q.: Manag. Inf. Syst. 2003, 27, 183-194. [CrossRef]

64. Rosemann, M.; Vessey, I. Toward improving the relevance of information systems research to practice: The role of applicability checks. MIS Q.: Manag. Inf. Syst. 2008, 32, 7-22. [CrossRef]

65. Fredricks, J.A.; Blumenfeld, P.C.; Paris, A.H. School engagement: Potential of the concept, state of the evidence. Rev. Educ. Res. 2004, 74, 59-109. [CrossRef]

66. Sayaf, A.M.; Alamri, M.M.; Alqahtani, M.A.; Al-Rahmi, W.M. Information and Communications Technology Used in Higher Education: An Empirical Study on Digital Learning as Sustainability. Sustainability 2021, 13, 7074. [CrossRef]

67. Luna-Krauletz, M.D. Juárez-Hernández, L.G.; Clark-Tapia, R.; Súcar-Súccar, S.T.; Alfonso-Corrado, C. Environmental Education for Sustainability in Higher Education Institutions: Design of an Instrument for Its Evaluation. Sustainability 2021, 13, 7129. [CrossRef]

68. Govender, T.; Arnedo-Moreno, J. An Analysis of Game Design Elements Used in Digital Game-Based Language Learning. Sustainability 2021, 13, 6679. [CrossRef] 